\title{
MANDI MALAM MENYEBABKAN RHEUMATOID ARHTRITIS (REMATIK): TELAAH SINGKAT
}

\author{
Eka Rachmawati $^{*}$, Anung Ahadi Pradana ${ }^{1}$ \\ ${ }^{1}$ Program Studi DIII Keperawatan, STIKes Mitra Keluarga Bekasi \\ *Corresponding Author: ekaarachmawati93@gmail.com
}

Kata Kunci: Mandi Malam, Mitos Kesehatan, Rematik, Telaah Naratif

DOUBT/DIFFERENCE

Benarkah mandi saat malam hari dapat menyebabkan rematik?

\section{DESCRIPTION}

Banyak masyarakat yang mempercayai bahwa mandi malam menyebabkan rematik. Penulis juga menemukan fenomena disekitar penulis dari kerabat dekat penulis, teman maupun masyarakat lingkungan penulis masih banyak yang beranggapan bahwa mandi malam dapat menyebabkan rematik. Hal ini juga di dukung dari hasil wawancara pada penelitian Sidik (2018):

"'oh setau ayuk rematik itu peradangan sendi yang disebabkan sendinya nyeri ya bengkak, kesemutan terus ngilu-ngilu apa ya sering kaku, kami sering ceritacerita mbah itu kan, mbah sering bilang juga oh dek kenapa dek aku ini sering sakit, ngilu-ngilu ya kata dia ya terus rasanya ya apa namanya seperti kesemutan itu, oh mbah itu mungkin rematik jangan sering mandi malam kata kami itu kan makanya kalau sering mandi malam itu bisa rematik kata kami jangan bermain air malam-malam itu kata kami“.

Gambaran wawancara di atas merupakan kondisi yang umum terjadi pada masyarakat Indonesia yang masih menganggap bahwa mandi malam dapat menyebabkan rematik.

\section{DISSECTION}

Rematik adalah perandangan pada sendi rematik disebabkan oleh adanya pengapuran sendi, sehingga penyakit ini akan mengalami nyeri sendi dan keterbatasan gerak (Damayanti, 2015). Selain itu, penyakit ini merupakan salah satu penyakit imun yang paling sering terjadi pada sendi dimana tanda gejala yang sering muncul meliputi: Nyeri, kekakuan sendi, pembengkakan dan kemerahan sendi (Perhimpunan Reumatologi Indonesia, 2020). Data Riset Kesehatan Dasar tahun 2018 menunjukkan bahwa jumlah penduduk Indonesia yang mengalami nyeri sendi (termasuk Rheumatoid arthritis, Osteoarthritis, dan Gout Arthritis/ asam urat) sebesar 713.783 orang atau $7,3 \%$ dari total penduduk, sementara data spesifik angka kejadian rematik belum diketahui (Kementrian Kesehatan Republik Indonesia, 2018). Faktor risiko yang menimbulkan rematik diantaranya usia, jenis kelamin, pola makan, aktivitas, genetik selain itu tingkat pengetahuan juga sangat berpengaruh (Meliny, Suhadi, dan Sety, 2018). Beberapa faktor di atas juga didukung oleh penelitian yang dilakukan Bawarodi, Rottie, \& Malara (2017a) yang menyebutkan bahwa 3 faktor utama yang dapat mempengaruhi kekambuhan dari rematik antara lain: tingkat pengetahuan dari si penderita, pekerjaan/ aktivitas sehari-hari, dan pola makan yang tinggi susu dan produk jeroan. 
Mandi malam tidak menyebabkan rematik namun air dan udara dingin memicu pengaruh sendi sehingga membuat persendian semakin nyeri, sehingga mandi malam tidak di anjurkan mandi air dingin tetapi yang dianjurkan adalah air hangat. Sedangkan masyarakat Indonesia memiliki persepsi bahwa mandi malam merupakan penyebab yang menyebabkan rematik. Oleh karena itu sangat penting memberikan edukasi terkait pengetahuan tentang rematik mengenai pengertian, penyebab dan faktor risiko rematik, tanda dan gejala, komplikasi dan pencegahan. Perawat harus mampu memberikan edukasi kesehatan kepada masyarakat.

\section{DISCOVER}

Rematik adalah penyakit yang tidak diketahui asalnya, yang ditandai dengan perubahan inflamasi pada jaringan sinovial sendi, tulang rawan dan tulang. Lingkungan sekitar seperti paparan asap rokok, debu dan mikroba tertentu diketahui dapat menjadi salah satu faktor eksternal yang dapat meningkatkan risiko terjadinya rematik di luar faktor internal (Ulrich, Häupl, \& Burmester, 2020). Pasien dapat pula menunjukkan gejala konstitusional berupa kelemahan umum, cepat lelah, atau gengguan nonartikular lain (Aspiani, 2014).

Rematik disebabkan oleh genetik, reaksi imunologi, usia lebih dari 40 tahun, jenis kelamin wanita, reaksi inflamasi pada sendi dan tendon, kepadatan tulang. Rematik paling banyak ditemui dari faktor, genetik, jenis kelamin, infeksi, berat badan/obesitas, usia, selain ini faktor lain yang mempengaruhi terhadap penyakit rematik adalah tingkat pengetahuan penyakit rematik sendiri memang masih sangat kurang, baik pada masyarakat awam maupun kalangan medis (Mansjoer, 2011). Faktor resiko penyebab rematik dapat dikelompokkan menjadi 2 yaitu faktor usia dan jenis kelamin, serta faktor genetik. Semakin bertambah usia, semakin tinggi resiko untuk terkena rematik. Wanita lebih rawan terkena rematik dibanding pria, dengan faktor risiko sebesar $60 \%$. Sedangkan faktor keturunan dapat menimbulkan rematik jenis tertentu, seperti rheumatoid arthritis (RA) serta Systemic Lupus Erythematosus (SLE) (Damayanti, 2015).

Beberapa karakteristik yang dapat meningkatkan risiko rematik antara lain: (Centers for disease control and prevention (CDC), 2020)

A. Usia, rematik dapat dimulai pada usia berapa pun, tetapi kemungkinan meningkat seiring bertambahnya usia. Onset rematik tertinggi di antara orang dewasa dan lansia sejak usia enam puluhan.

B. Jenis kelamin, kasus baru rematik biasanya dua hingga tiga kali lebih tinggi pada wanita daripada pria. Salah satu yang meningkatkan risiko arthritis rheumatoid pada wanita adalah menstruasi. Wanita dengan menstruasi yang tidak teratur atau riwayat menstruasi dipotong (misalnya, menopause dini) memiliki peningkatan risiko arthritis rheumatoid, hal ini disebabkan oleh massa otot di sekitar lutut perempuan lebih sedikit daripada laki-laki. Peran hormonal juga mempengaruhi terjadinya osteoartritis lutut karena pada masa mengalami menstruasi, kadar estrogen dalam tubuh meningkat sehingga perempuan amat rentan terkena cedera lutut (Langow, Sandra, dan Sintya 2018). 
C. Pola diit/ konsumsi dan aktivitas, Berdasarkan hasil penelitian Bawarodi , Rottie, dan Malara (2017) adanya hubungan kekambuhan rematik dengan pengetahuan, pola makan dan aktivitas atau pekerjaan. Didapatkan hasil responden 3 responden $(12,5 \%)$ pengetahuan tidak baik mengalami kekambuhan rematik dan 21 responden $(87,5 \%)$ baik, hasil penelitian ini didukung karena adanya faktor lain seperti sikap responden yang cenderung lebih acuh tak acuh dengan penyakitnya, $3(33,3 \%)$ responden memiliki pola makan tidak baik tetapi tidak mengalami kekambuhan, dan 23 (79,3\%) responden memiliki pola makan yang baik tetapi mengalami kekambuhan disebabkan karena adanya kebiasaan mengomsumsi makanan yaitu yang dapat memicu terjadinya kekambuhan rematik, 9 responden tidak terganggu dengan aktivitas dalam kekambuhan rematik, dan 23 responden terganggu dengan aktivitas dalam kekambuhan rematik hal ini disebabkan aktivitas dengan beban pekerja dan daya tekanannya yang dapat memperberat sendi dan pekerjaan yang banyak menggunakan tangan dalam jangka waktu yang lama, sering yang menjadi keluhan-keluhan yang dapat dirasakan pada setiap penderita penyakit rematik. Hal ini didukung dengan hasil penelitian Putri Ardi (2018) adanya hubungan aktivitas fisik dengan rematik yaitu didapatkan hasil 36 responden $(49,3 \%)$ baik dan 37 responden (50,7\%) kurang baik.

D. Genetika/sifat yang diturunkan, orang yang lahir dengan gen tertentu lebih mungkin mengembangkan rematik. Gen-gen ini, yang disebut genotipe kelas II HLA (human leukocyte antigen), juga dapat memperburuk radang sendi Seseorang. Risiko rematik mungkin paling tinggi ketika orang dengan gen ini terpapar faktor lingkungan seperti merokok atau ketika seseorang mengalami obesitas.

E. Merokok, Berbagai penelitian menunjukkan bahwa merokok meningkatkan risiko seseorang terkena rematik dan dapat memperburuk penyakit.

F. Riwayat partus, Wanita yang belum pernah melahirkan mungkin berisiko lebih besar terkena rematik.

G. Paparan di Kehidupan Awal, Beberapa paparan kehidupan awal dapat meningkatkan risiko mengembangkan rematik di masa dewasa. Misalnya, satu penelitian menemukan bahwa anak-anak yang ibunya merokok memiliki risiko dua kali lipat terkena rematik saat dewasa. Anak-anak dari orang tua berpenghasilan rendah berada pada peningkatan risiko mengembangkan rematik sebagai orang dewasa.

H. Obesitas, Menjadi gemuk dapat meningkatkan risiko mengembangkan rematik. Studi yang meneliti peran obesitas juga menemukan bahwa semakin berat badan seseorang, semakin tinggi risikonya terkena rematik. Berdasarkan hasil penelitian yang dilakukan oleh Meliny, Suhadi, dan Suty (2018) faktor risiko yang dapat menyebabkan rematik adalah faktor gaya hidup, IMT, pengetahuan, dan pola makan. Didapatkan hasil 66 responden $(72,5 \%)$ mimiliki gaya hidup kurang baik dan 25 responden $(27,4 \%)$ memiliki gaya hidup baik, 62 responden $(68,13 \%)$ memiliki IMT kurang baik, dan 29 responden $(31,87 \%)$ memiliki IMT baik, 60 responden $(65,9 \%)$ pengetahuan kurang baik, 31 responden $(34,0 \%)$ pengetahuan baik, 64 responden $(70,3 \%)$ memiliki pola makan kurang baik, dan 27 responden $(29,6 \%)$ pola makan baik. Hal ini didukung dari hasil penelitian yang dilakukan oleh Oktarini (2020) didapatkan hasil 40 responden $(54,8 \%)$ mempunyai riwayat jenis 
makanan tidak baik dan 33 responden $(45,2 \%)$ mempunyai riwayat jenis makanan baik Riwayat mengkonsumsi makanan tidak baik seperti mengkonsumsi jeroan (hati, limpa, ginjal usus), makanan kalengan, diawetkan, kacang-kacangan, dan makanan cepat saji serta makanan yang menggunakan bahan penyedap menjadi faktor risiko rematikan dan menjadi pencetus kekambuhan penderita rematik.

I. Sementara terdapat 1 karakteristik yang dapat mengurangi risiko

Rematik, yaitu menyusui, wanita yang menyusui bayinya secara eksklusif diketahui memiliki risiko lebih rendah terkena rematik dibandingkan mereka yang tidak.

Gejala peradangan rematik cenderung lengkap, yaitu, terjadi pembengkakan, muncul kemerahan di kulit, terasa nyeri dan panas pada sendi yang terserang, dan biasanya, sendi menjadi sulit untu digerakkan. Nyeri sendi dengan tanda radang yang tidak lengkap (atropik). Misalnya, terjadi pembengkakan pada tulang, bukan pada jaringan lunak atau, terjadi pembengkakan tulang yang diikuti dengan gangguan fungsi tulang, tetapi tidak muncul kemerahan di kulit atau rasa panas (Junaidi \& Iskandar, 2013). Pengobatan kondisi rematik pada beberapa pasien sering kali tidak mendapatkan hasil yang maksimal akibat beberapa kondisi tertentu seperti autoantibodi, adanya komorbid, kehamilan dan erosi sendi yang masif. Faktor lain seperti pola makan dan perilaku merokok juga dapat mempengaruhi kerentanan seseorang terhadap penyakit autoimun, sementara pola diet mediterania, asupan rendah garam, konsumsi coklat, temulawak dan aktivitas fisik memiliki efek positif dalam menurunkan risiko terjadinya rematik (Conigliaro dkk., 2019).

\section{DECISION}

Saya tidak setuju jika mandi malam menyebabkan rematik. Hal ini karena rematik itu sendiri peradangan pada sendi yang disebabkan karena faktor usia, jenis kelamin, pola makan, genetik, dan aktivitas selain ini faktor lain yang mempengaruhi terhadap penyakit rematik adalah tingkat pengetahuan penyakit rematik sendiri memang masih sangat kurang, baik pada masyarakat awam. National Health System (NHS) UK (2019) menyebutkan bahwa hingga saat ini belum ada obat untuk rheumatoid arthritis. Namun, diagnosis dini dan perawatan yang tepat memungkinkan banyak orang dengan kondisi tersebut memiliki periode hidup normal berbulan-bulan atau bahkan bertahun-tahun kemudian. Hal ini dapat membantu mereka menjalani kehidupan penuh dan melanjutkan pekerjaan tetap. Pilihan pengobatan utama yang disarankan meliputi:

A. Obat yang diminum dalam jangka panjang untuk meredakan gejala dan memperlambat perkembangan kondisi rematik.

B. Perawatan suportif, seperti fisioterapi dan terapi okupasi, untuk membantu individu tetap bergerak dan mengatasi masalah apa pun yang dialami.

C. Operasi untuk memperbaiki masalah sendi yang berkembang semakin parah.

Sementara beberapa hal yang dapat dilakukan oleh tenaga kesehatan dalam mendampingi pasien rematik antara lain:

A. Melakukan Pendidikan kesehatan, Pendidikan kesehatan yang dilakukan bedasarkan sumber yang terpercaya dalam menekankan mandi malam bukan 
faktor yang menyebabkan rematik. Edukasi harus ini dilakukan secara terus menerus Pendidikan kesehatan yang diberikan meliputi:

1. Pengertian,

2. Penyebab dan faktor risiko

3. Tanda dan gejala

4. Patofisiologi, (perjalanan penyakit)

5. Komplikasi

6. Pencegahan

B. Mengajarkan Terapi Komplementer Kompres jahe hangat, Hasil implementasi EBN terapi Kompres jahe hangat sangat berpengaruh dalam menurunkan intensitas nyeri sendi pada pasien Rematik. Pemberian intervensi kompres hangat jahe selama 7 hari menunjukkan penurunan skala nyeri pasien dari skala nyeri 4-5 menjadi skala nyer 1-2 (Octa \& Febrina, 2020).

C. Mengajarkan Terapi Senam Rematik, Penelitian yang dilakukan Afnuhazi (2018) tentang efektivitas terapi senam rematik pada 16 lansia selama 1 bulan menunjukkan adanya pengaruh positif dalam penurunan skala nyeri akibat rematik yang dialami dengan pelaksanaan senam rematik secara rutin.

D. Penatalaksanaan medis, Pemberian obat anti inflamasi non-steroid (AINS) memiliki efektivitas lebih tinggi dalam mengontrol rasa sakit dibandingkan dengan obat analgetik, akan tetapi memiliki efek samping yang jauh lebih berbahaya dan dapat berakibat fatal. Beberapa pertimbangan yang perlu diperhatikan dalam pemilihan AINS antara lain 1) AINS terdistribusi ke sinovium, 2) mula kerja AINS segera (dini), 3) masa kerja AINS lama (panjang), 4) bahan aktif AINS bukan rasemik, 5) bahan aktif AINS bukan prodrug, 6) efek samping AINS minimal, 7) memberikan interaksi yang minimal dan 8) dengan mekanisme kerja multifactor. (Lelo, Hidayat, \& Juli, 2014)

E. Mendiskusikan pilihan Terapi Lain Seperti Fisioterapi atau Bedah.

\section{UCAPAN TERIMA KASIH}

Ucapan terimakasih kepada bapak Ns. Anung Ahadi Pradana, M.Kep., Sp.Kep, Kom yang telah membimbing dalam menulis naskah essai ini.

\section{DAFTAR PUSTAKA}

Afnuhazi, R. (2018). PENGARUH SENAM REMATIK TERHADAP PENURUNAN NYERI REMATIK PADA LANSIA. MENARA Ilmu, XII(1), 117-126. Retrieved from http://jurnal.umsb.ac.id/index.php/menarailmu/article/viewFile/494/433

Aspiani. (2014). Asuhan Keperawatan Gerontik Aplikasi Nanda Nic dan Noc. Jakarta. Jakarta: Trans Info Media.

Bawarodi, F., Rottie, J., \& Malara, R. (2017a). FAKTOR-FAKTOR YANG BERHUBUNGAN DENGAN KEKAMBUHAN PENYAKIT REMATIK DI WILAYAH PUSKESMAS BEO KABUPATEN TALAUD. E-Journal Keperawatan (E-Kp), 5(1), 1-7. Retrieved from https://ejournal.unsrat.ac.id/index.php/jkp/article/download/15955/15471

Bawarodi, Rottie, \& Malara. (2017b). FAKTOR-FAKTOR YANG BERHUBUNGAN DENGAN KEKAMBUHAN PENYAKIT REMATIK DI WILAYAH, 5(1), 1-7. https://doi.org/10.4018/978-1-4666-2673-7 
Centers for disease control and prevention (CDC). (2020). Rheumatoid Arthritis (RA). Retrieved from https://www.cdc.gov/arthritis/basics/rheumatoidarthritis.html

Conigliaro, P., Triggianese, P., Martino, E. De, Fonti, G. L., Chimenti, M. S., Sunzini, F., ... Perricone, R. (2019). Autoimmunity Reviews Challenges in the treatment of Rheumatoid Arthritis. Autoimmunity Reviews, 18(7), 706713. https://doi.org/10.1016/j.autrev.2019.05.007

Damayanti. (2015). Arthritis Rheumatoid Dan penatalaksanaan Keperawatan. Yogyakarta: Nuha Medika.

Junaidi, \& Iskandar. (2013). Rematik dan Asam Urat. Jakarta: PT Bhuana Ilmu Populer.

Kementrian Kesehatan Republik Indonesia. (2018). Laporan Nasional Riset Kesehatan Dasar 2018 (1st ed.). Jakarta: Kemenkes RI.

Langow, Sandra, \& Sintya. (2018). Penyakit Rematik Autoimun. Jakarta: elexs Media Komputindo.

Lelo, A., Hidayat, D. S., \& Juli, S. (2014). Penggunaan Anti-Inflamasi NonSteroid Yang Rasional Pada Penanggulangan Nyeri Rematik. ResearchGate. Retrieved from https://www.researchgate.net/profile/AznanLelo/publication/242289463_Penggunaan_Anti-

Inflamasi_NonSteroid_Yang_Rasional_Pada_Penanggulangan_Nyeri_Remat ik/links/5a7917e70f7e9b41dbd449a4/Penggunaan-Anti-Inflamasi-

NonSteroid-Yang-Rasional-Pada-Penanggulangan-Nyeri-Rematik.pdf

Mansjoer. (2011). Kapita Selecta Kedokteran Jilid 1 Edisi. Jakarta: EGC.

Meliny, Suhadi, \& Sety, M. (2018). Analisis Faktor Risiko Rematik Usia 45-54 Tahun di Wilayah Kerja Puskesmas Puuwatu Kota Kendari Tahun 2017. Jurnal Ilmiah Mahasiswa Kesehatan Masyarakat, 2(2), 1-7.

NHS UK. (2019). Rheumatoid arthritis. Retrieved from https://www.nhs.uk/conditions/rheumatoid-arthritis/

Octa, A. R., \& Febrina, W. (2020). Implementasi Evidence Based Nursing Pada Pasien Rematik: Studi Kasus. REAL in Nursing Journal (RNJ), 3(1), 55-60. https://doi.org/10.32883/rnj.v3i1.763.g244

Oktarini, S. (2020). HUBUNGAN RIWAYAT JENIS MAKANAN, LINGKUNGAN DAN OLAHRAGA DENGAN KEJADIAN REMATIK PADA LANSIA. Jurnal Menara Medika, 2(2), 119-127.

Perhimpunan Reumatologi Indonesia. (2020). Artritis Reumatoid. Retrieved from https://reumatologi.or.id/wp-content/uploads/2020/09/RheumatoidArthritis.pdf

Putri Ardi, A. (2018). Hubungan Jenis Makanan dan Aktifitas Fisik dengan Kejadian Rematik pada Lanjut Usia di Jorong Padang Bintungan di Wilayah Kerja Puskesmas Koto Baru Kabupaten Dharmasraya. MENARA Ilmu, $X I I(6), 20-26$.

Sidik, A. B. (2018). Pengalaman Lansia Dalam Mengatasi Nyeri Arthritis Rheumatoid Di Panti Sosial Tresna Werdha Sumatera Selatan Tahun 2017. Jurnal 'Aisyiyah Medika, 2, 153-163.

Ulrich, H., Häupl, T., \& Burmester, G. R. (2020). The etiology of rheumatoid arthritis. Journal of Autoimmunity, (December 2019), 1-15. https://doi.org/10.1016/j.jaut.2019.102400 